Review Article

\title{
PAUL AS A LETTER WRITER \\ A NEW PUBLICATION ON PAULINE LETTERS IN THEIR LITERARY SETTING
}

\author{
Pieter GR de Villiers \\ Department of New Testament \\ University of the Free State
}

\begin{abstract}
This article discusses Stirewalt's new publication (2003) on Paul as a letter writer in the light of research on letters in New Testament Studies. After an introductory discussion of pioneering work by Deissmann, trends in twentieth century research on letter writing are analysed as framework for a discussion of the work of Stirewalt. This is followed by reflection on some seminal issues raised by this work, like practicalities of letter writing, comparative methods, missiological issues, and spirituality.
\end{abstract}

\section{Introduction}

After the discovery of many papyrus documents and ostraca, the German scholar, Deissmann, understanding how revolutionary their impact on the understanding of the New Testament and its social context is, published two publications on them at the beginning of the twentieth century. ${ }^{1}$ Given his special gift for popularising his insights (Meeks 1983:51), ${ }^{2}$ it is not surprising that his two works, translated in English as Bible Studies and Light from the Ancient East, became classics in the field on New Testament Studies, reprinted many times.

Deissmann is, of course, especially known for his much discussed distinction between public epistles with a literary character and personal, informal, and non-literary letters (218-230), but his work generally set the tone and opened the way for later research on letters and letter writing. This research ultimately impacted on hermeneutical issues and the nature of early Christianity. How significant this work can be, is evident from some of the conclusions that Deissmann drew. Head (2001), for example, spelled this out by referring to observations made by Deissmann about his own findings:

The task of exegesis becomes spontaneously one of psychological reproduction when once the ebb and flow of the writer's temporary moods is duly recognised. The single confessions in the letters of a nature so impulsive as St. Paul's were dashed down under the influence of a hundred various impressions, and were never calculated for systematic presentment. The strange attempt to paste them together mechanically, in the

1. Note, for example, Hercher (1873) and Hermann (1901) as an indication of what was being researched in that time in a similar context.

2. His two long journeys to the world within which the New Testament originated, led him to write about Paul "in terms of a vivid, thoroughly romantic travalogue" (Meeks 1983:51) - reminding one of the similar influence of William Ramsay, the other inveterate and romantic traveller to that region, who also produced very popular writings on New Testament studies. 
belief that in this way Paulinism may be reconstructed, will have to be given up. Thus, Paulinism will become more enigmatical, but Paul himself will be seen more clearly; a non-literary man of the non-literary class in the Imperial age, but prophet-like rising above his class and surveying the contemporary educated world with the consciousness of superior strength ( $L A E, 233 \mathrm{f})$.

These remarks are the obvious results of Deissmann's classification of Paul's letters as private and informal and his claims about the low social context in which they originated. In subsequent research, Deissmann was criticized for this unsubstantiated view on the social level of Christianity, ${ }^{3}$ whilst it was also argued that he artificially distinguished between official and private letters and reduced a complex genre in an illegitimate manner to these two types. ${ }^{4}$ Ironically, this criticism is based on readings of the same letters he claimed in support of his views, confirming the careful analysis they require, but also how fundamental they are for an understanding of Christianity and the Bible.

Deissmann's publication is often regarded as a beacon in research on the letters (e.g. Stowers 1986) because it opened the eyes for the nature of their genre and stimulated key areas of research in modern Biblical Studies. He is indeed a pioneer in the comparative analysis of ancient letters (cf. Aune 1987:160). It is this, rather than the precise detail in his works, that should be remembered when publications on the field are studied.

It is against this background that one should read Stirewalt's new publication (2003). His book reflects a debate over a long period within an established field of research that evaluates New Testament letters in terms of ancient letter conventions. In doing so, he continues work begun by Deissmann. However, more importantly, it is also only when his work is compared with that of Deissmann that one realizes how far the discipline has advanced, but especially how decisive the role of the interpreter is in the research process. Stirewalt reflects the changes mentioned in the previous paragraph when he defends viewpoints that differ radically from Deissmann, for example, in terms of the general distinction between private and official types of letters. Whilst Deissmann saw Paul as a writer of private letters, Stirewalt reads him radically different, regarding him, in the light of ancient letter conventions, as a writer of official letters. ${ }^{5}$ This position works itself out in Stirewalt's different theological comments on the work of Paul and the nature of his letters. It makes fascinating reading to survey the field in this manner.

3. Already by Ramsay (1904:23ff.). Deissmann's remarks on the status of early Christians provoked much debate over a long time and influenced many to regard Christianity as a movement of the lower classes. Meeks (1983:51-2) remains the most profound source for insightful comments on this issue, pointing out the right direction for a proper analysis of the social status of early Christianity. His nuanced position is clear when he shows how Deissmann remarked carefully on the amibiguity of his sources on this matter, other than his interpreters and followers indicated. Note especially what Meeks quotes from Deissmann about Paul's language and his links with the "middle" classes.

4. Finkenroth (1986:246), for example, writes more carefully, but in Deissmann's vein, "With the spread of Hel. culture a whole range of letters was developed, from private letters of an intimate nature, open letters (e.g. the didactic letters of the Epicurean philosophers), to artistic epistles, which were aesthetic treatises in letter form. Travelling philosophers and their pupils were accustomed to carry the letters of recommendation (Diog.Laert., 7,1; 3; 7,8,87)." Cf. also, e.g., Aune (1987:160) who notes that Deissmann's distinction "obscured rather than clarified the spectrum of possibilities that separated the short personal letter from the literary letters of antiquity."

5. Stirewalt thus joins other researchers like Aune (1987:160) who note that comparative work indicates that there are no private letters among Paul's authentic letters. 


\section{Research on Letter Writing since Deissmann}

Significant research on letter writing began to surface slowly, but surely in the decades following Deissmann's publication. Aune (1987:183) helpfully suggests that this research took the three routes of formal literary analysis, thematic analysis, and rhetorical analysis. A few major names and topics from this research will illuminate the scope and nodal points of the research.

In the first half of the twentieth century, there were a small number of significant publications. Literary analysis was made easier by the publication of more papyrus letters in certain collections (e.g. Hunt and Edgar:1932-1934). In classics, Exler ([1923]) and Bradford Welles (1934) published influential works on letters, providing more primary sources for Biblical research on the field (cf. White 1982 on these early works). Within New Testament Studies the works by Otto (1933) who investigated the form of Pauline letters, by Schubert (1939) who analysed how Paul shared characteristics of certain letters of his time and by Koskenniemi (1956) who published thematic studies on Greek letters, stood out and represented key works that stimulated more research.

In the second half of the twentieth century, research strongly moved ahead. Well-known examples of the link between letters and the New Testament include Rigaux (1962) and Bahr $(1966,1968)$ who analysed Paul's letters, and Kim (1972) who studied letters from the papyri and reflected on their relevance for the New Testament. In this period literary analysis got under way when, amongst others, Mullins (cf. 1962, 1964, 1968; 1972) studied such topics as greeting, petitions and formulas in New Testament letters. Doty, a well known researcher in letter research in the second half of the previous century, $(1969 ; 1973)$ drew up a survey of letters in early Christianity (cf. also Berger 1974).

The study of letters was stimulated, however, in a major way first by a consultation and then by a group of the Society of Biblical Literature on Ancient Epistolography that was established in the seventies. This group included such researchers like Dahl, White, ${ }^{6}$ Funk (1967), Betz (1979), and Stirewalt - all well known scholars and leading researchers in the discipline. ${ }^{7}$ It is an indication of the special place of this society in Biblical Studies as a discipline that it provided a forum where knowledgeable scholars who recognized the importance of a potentially important tool for Biblical Studies could get together and share their expertise. It is also an indication of the importance of the topic that they as individuals agreed that the time was ripe for extensive and coherent work on it.

In an interesting historical reflection, White (1982; cf, also Hester s.a.) discussed the context and development of the research done by this group. He noted that its work was stimulated in a wider sense by remarks of Bradford Welles (later on confirmed by Schubert), about the incomplete state of knowledge regarding Greek letters and the need to study aspects of these letters in their social context (1982:1). The major impulse, however, seemed to have been the intellectual climate and contact among prominent researchers in North America. White, for example, remarks that his own initiative and participation in the SBL group was a result of work previously done in the Society's Paul Seminar where he

6. White wrote several publications on letters. In Light from Ancient Letters (1986), he integrated New Testament letters in their literary contexts, analysing their literary form and the language characteristic of this form, but also stressing the need to understand them in the light of the letters of that time. Cf. the literature at the end of this essay for a list of works by White and the other participants mentioned here.

7. There are other prominent researchers like Stowers, Epp, Longenecker, Malherbe and quite a few others that contributed significantly to letter research. Note also the publication of such publications as that of Thraede (1970) and Cancik (1967) in these times. These are all indications of how research on various facets of letter writing got underway during this time. 
became aware of the significance of literary letter tradition for understanding Paul as a letter writer $(1982: 2){ }^{8}$ Equally interesting is that the work was not merely comparative in nature, that is, merely studying the sources in so far as they illuminate the New Testament. Initial work of the group included reflection on Hellenistic Aramaic and Akkadian letters. The publication of some epistolary tools (cf. White 1982:3-4) and extensive work on Ancient Near Eastern letters followed. Subsequent sessions worked on the classification of epistolary types and sub-types, the study of epistolary conventions in the letter-body and the identification of epistolary formulas (cf. White 1982:4). Although the group decided to study letters in antiquity for their own worth, the value of such research for the interpretation of the Pauline letters was also spelled (cf. White 1982:2) out. It is, in fact, striking how extensively modern epistolographical research investigated New Testament letters in the light of Graeco-Roman literature.

The years following the groundbreaking work of the SBL group saw many such studies. There were general studies, like, for example, that of Aune (1987) who made valuable information on these texts available in a series edited by Meeks (Library of Early Christianity). Aune allocated two chapters to letters, discussing, firstly, letters in the ancient world and then, secondly, early Christian letters and homilies. In 1988, Malherbe focused on epistolary theorists from this time and provided insightful examples from specific documents. Specialized studies like those of Richards (1991) on the secretary in Paul's letters and Arzt (1994) on thanksgivings in the introductions of letters in the papyri and Paul appeared. Group work in other contexts also continued to advance the study of letters. The research on friendship by the Hellenistic Moral Philosophy and Early Christianity Group, for example, offered useful insights into the nature of letters (cf. Stirewalt 2003:81-91).

An indication of the way in which the field of research on letter writing has expanded in other countries, is found in the research project with the title, Pauline Letters \& Documentary Papyri that is run by the Institute for New Testament Studies of the University of Salzburg. On their website they define the project as an investigation of the use of the papyri and ostraca to illumine the text, language, society, and thought of the New Testament. In this context, they research common motifs, formulars and language in New Testament and secular epistolographical literature, especially in documentary papyri and related material. Their ultimate aim is to publish commentaries on the Pauline letters based on papyrological evidence. This project is an example of how important research on New Testament letters has become in the study of the discipline in many different parts of the world.

It is within this wider frameword that the publication of Stirewalt should be understood. He was previously involved in the general study of letters in antiquity, reading them as a collection and in their own right (1993). That influential publication discussed what kinds of letters gradually developed in antiquity, such as, for instance, letters on major philosophical and technical themes. He also discussed the function of letters there, noting that in ancient theorists letters cemented bonds of friendship, whilst personal letters were used for many other functions in business, burocracy and education, requesting financial support or containing recommendations. Fictional letters (e.g. romantic letters), for example, were used to entertain, whilst letter writing in a school setting served to promote education. ${ }^{9}$ Stirewalt's

8. It is not without importance that he sensed this during an exercise that focussed on form critical work on Paul's texts. During this same time with remarkable similar dynamics, form critical work on apocalypses led to decisive new insights in the genre of those texts, as Semeia 14 (1979) proves.

9. Aune (1987:219) also illustrates the importance of function: Romans is on one level epideictic, revealing Paul's position on important theological issues. On another level it is protreptic, demonstrating the truth of the gospel and calling the readers to commit themselves to it. "The complex theological argumentation in Rom.12:1-15:13 must have been developed by Paul during many years of preaching and teaching (even the 
book on Paul as letter writer builds on this work (cf. also White 1972;1986). Having established himself as one of the most senior researchers in the field generally, he moves on to focus in his new publication specifically on Paul as a letter writer.

This neatly edited text of Stirewalt is a treasure trove of information. The simplicity of its presentation may be deceptive, causing the reader to overlook the wealth of information in the text, footnotes and bibliography on recent research and primary sources. Despite its limited scope and its disciplined focus, there are, therefore, enough aids and information in it that suggest to the reader how to pursue the journey of understanding Paul as letter writer further.

The nature and contents of the book can be discussed, therefore, only cursorily in the present context. When the following points are raised, it is done without trying to be exhaustive, and onloy in order to bring out the value of the book within the discipline as a whole and in the interpretive activity in New Testament Studies.

\section{Practical Issues: The Logistics of Letter Writing}

Meeks (1983:6) famously stated that, whilst many Bible readers talk easily about the contents and theology of Biblical texts, not many can explain how it must have been to be an ordinary Christian in everyday life of those times. Those who have kept abreast of research on letters know how this situation has changed dramatically as extensive attention was given to the practicalities of letter writing in recent research (e.g. Stirewalt 1969; Epp 1991 and Mitchel 1992).

Stirewalt's book excells in this respect, opening with a first chapter on the logistics of ancient Greek letter writing in which he writes about public and private letters before discussing in a simple, practical manner the preparation, delivery and reception of letters. He notes, for example, how official letters were delivered in the later Hellenistic period by a well established official postal service. ${ }^{10} \mathrm{He}$ gives excellent readings from ancient sources, but also refers to pivotal research that was done on these issues. He explains, for example, the letter of the Jerusalem Council to Antioch (Acts 15) in an illuminating way by referring to the offical letter from the Athenian general, Nicias, to Athens to report on an expedition that went wrong in Sicily (Stirewalt 2003:6). ${ }^{11}$ Although messengers who carried that letter gave an oral report, the letter itself functioned to convey reliable information.

taks of composing Romans must have taken many months)." The thorny issue in the discussion of literary matters like function is that the method of analysis is, in most of these cases, basically phenomenologically, lacking explicit theory formation. Whilst such a phenomenological approach has its merits, theory regarding the nature of function may help steer research decisively and cope with difficulties caused by a too simpistic descriptive approach. In the SBL group on apocalypses, Hellholm (1986) contributed theoretical reflection that strongly influenced the work of the group.

10. Within the limited scope and specific aim of his book, the literature and references on private correspondence are not exhaustive. Stirewalt notes that private letters were delivered by slaves, traders or family members. Other examples can be given. Arzt (2001), for instance, mentions P. Oxy 2719 (III), an interesting example of directions given to someone who was to deliver a letter that is not found in Stirewalt's publication. The reference is so noteworthy because it illustrates how concrete research on this issue is. Arzt refers to Llewelyn (1994) and Epp (1991). "Consignment of Rufus' letters: From the Moon gate walk as if towards the granaries and when you come to the first street turn left behind the thermae, where there is a shrine, and go westwards. Go down the steps and up the others and turn right and after the precinct of the temple on the right side there is a seven-storey house and on top of the gatehouse a statue of Fortune and opposite a basket-weaving shop. Enquire there or from the concierge and you will be informed. And shout yourself; Lusius will answer you...".

11. Illuminating is his reference to the letter of the High Priest authorizing Paul's expedition against Christians (Stirewalt 2003:19). 
The short introduction on the logistics of letter writing is concluded by a description of letter writing by Paul. The focus of this chapter is clear: "The logistics of letter writing in Paul resembles that of official correspondence rather than personal letters." It is a fundamental thesis of his book that Paul's letters are closest to this officical type of letter (2003:19). ${ }^{12}$ This is evident from the fact that both secular and Pauline texts identify a primary sender, name cosenders, contains multiple address, with a dual structure of and subscriptions to the body.

This focus on practicalities has significant consequences, since these "logistic define the context and identify the genre of the documents, but also influence the writer's method of composition" (Stirewalt 2003:24). This concrete information is therefore not merely helpful, but essential for the understanding of New Testament letter collections. It is an insight that is shared by, for example, Aune who wrote similarly in another context on rhetorical features in letters, noting that the social status and relationship of sender and receiver inevitably influence what is said in a letter and how it is said. This is because "systems of etiquette prescribed socially appropriate modes of behavior and speech for relating to persons of higher, equal, or lower social status in various situations" (Aune 1987:158). Such practical knowledge of rhetoric and practicalities helps us understand the nature, function and contents of letters, as will become clear in more detail below.

\section{The Unique Nature of Paul's Letters}

Comparative work sometimes tends to a mere listing of parallels or to forget that models of genre are by nature preliminary and need to be developed in a constant interchange with with the data under review. ${ }^{13}$ It is a major feature of this publication that Stirewalt works here as patiently through Pauline texts as he did on non-Biblical letters in his previous publication. This text analysis then allows for Pauline creativity to come to the fore, in the sense that not the model of the genre but the actual texts are also taken seriously by the analyst. There is also a second form of openness, in the sense that there is space for the dynamics of Paul's own development as letter writes. He is protrayed as moving between different subgenres of letters in his creative work. In one instance, for example, Paul may be closer to one type of subgenre, in another case he may be nearer to another type.

Paul's letters are thus recognized for their general uniqueness, despite general similarities with secular letters. In other words, Stirewalt does not naively regard Paul's letters as mere replicas of official letters. Each one of Paul's letters displays an own identity. They are not only unique because of their theological contents, but also because of the way in which Paul merged various available letter settings, forms and conventions in each (Stirewalt 2003:54-5). Whilst, for example, Paul is still struggling with the letter form in his first preserved letter, 1 Thessalonians, revealing reservations about writing, he is more assertive in Corinthians, moving beyond the pastoral concern of 1 Thessalonians towards a more authoritative, detached and rhetorically loaded communication in their situation of conflict. ${ }^{14}$ And, finally, in the case of Romans, Paul is much closer to a literary type of

12. Stirewalt (2003:28) writes that letters of political officials were widely heard in public readings, displayed in temples, in other buildings and along the highways so that their influence was "universal during the centuries surrounding Paul's life." Otherwise he focusses in more depth on the three types of official letters (that is, reports to a constituted body, executive or administrative letters and private letters written to public officials).

13. Aune (1987:203), for example, correctly criticizes rigid attempts to classify early Christian letters because they "run the risk of imposing external categories on Paul thereby obscuring the real purpose and structure of his letters."

14. His interpretation of 1 Corinthians as an official letter, for example, has far-reaching consequences for the understanding of its unity (cf. e.g. Stirewalt 2003:74). 
letters because of the unique situation in Rome. ${ }^{15}$ The integrity of each of Paul's letters is respected, avoiding a reading that rigidly forces them in a particular model of an official letter.

\section{Missiological Implications}

It has briefly been pointed out above that letter writing is essential to understand Paul. This book by Stirewalt is so illuminating because it weighs precise and careful historical work in terms of its theological implications. Readers soon realize that the matter under discussion is not peripheral, the qaint result of some obscure work of a highly specialized researcher.

We are offered valuable missiological perspectives as a result of the literary and contextual information developed in the book: Paul's letters fitted into an official context in which his "staff of volunteers" supported him in the production of his letters and integrated these documents in an "organized and dependable" postal service (2003:19). These remarks once again have striking consequences: "His supervising of preparation and delivery and the certainty of reception provided security of his epistolary ministry." This management style makes good sense in the light of the liminal and frail situation of many believers in Pauline churches after their conversion and after Paul moved on to new mission fields. Letter writing thus becomes not merely one of Paul's many creative activities. The logistics reflect priority, a sense of urgency in estalishing structures of support. We feel this "either from the presence of emissiaries waiting to return home to deliver the letter and make their reports... or in light of the knowledge that communication by letter always involved a hiatus of contact. The evidence also shows that the writer, having once accepted the medium, could not suppress an enthusiasm for writing and a pleasure in the opportunity to fulfill his office" (2003:24).

These remarks remind one of what Deissmann wrote about Paul's impulsiveness (quoted above), portraying Paul as a rather unsystematic passionate individual. Stirewalt also mediates a humane picture of a caring Paul, but in more sober language. With more convincing evidence than Deissmann, he portrays Paul as deeply and urgently involved in the well-being of others, dedicated to a vision and task that filled and drove his life. His picture transcends the impulsive, the individual and the mere emotional image of Paul that Deissmann projects.

This general portrayal greatly affects one's reading of individual texts. It helps one reread, for instance, the long list of names and remarks in Romans 15-16 as more than a tedious listing of endless names and moralistic injunctions, but rather as indications of a uniquely involved pastoral ministry and of a sensitivity for human relationships. In Romans as a reflective book written over a period of time at a strategic juncture in Paul's missiological work, Paul adds lists of names of people involved in his mission as coworkers and co-believers also to serve the function of his letter in his overall missiological strategy.

The book of Stirewalt thus brings Pauline letters into focus in a way that was unthinkable in previous decades. He helps the reader to appreciate the public nature of Paul's mision, his determined efforts to structure his missions and, perhaps even more significant, the corporate nature of Pauline missions much more. In fact, this book will be

15. Stirewalt (2003:112) concludes his observations on Romans by writing, "The letter of Romans is a disclosure of Paul's future plans, a spontaneous review of his ministry, and a résumé of his ponderings to date concerning responses to his gospel and to all others who may have opportunity to hear it. And it assumes the form of the letter-essay, a document uniquely suited to encompass these purposes." 
helpful in articulating and promoting a deeply felt need for a missiological reading of Pauline texts as one of the first priorities in New Testament studies.

\section{Formal Features}

It has been pointed out above how Stirewalt follows the texts of the Pauline letters in his discussions of Paul as letter writer. The third chapter of this book focusses extensively on the undisputed letters of Paul, as mentioned briefly above. He discusses the nature of 1 Thessalonians, 1 Corinthians, 2 Corinthians, Philippians, Philemon, Galatians and Romans, comparing some of these letters in an illuminating manner with specific secular official letters or topoi. In this way the link with the context and parallels with other texts are kept in focus and the discussion anchored in the study of texts. In each case the Pauline letter is compared with one such letter. Galatians is compared, for instance, with a writing by Antigonus to Scepsis, Philippians with the topos of friendship, 1 and 2 Corinthians with a letter to the Guild of Dionysiac Artists. Though the discussion is kept simple, the contextual perspectives are not neglected.

How important such a comparison can be, is illustrated by his reflections on 1 Corinthians that Stirewalt compares with a letter from Claudius to Alexandria. This comparison reveals the focus and unity of the letter: working with the four $\square \mathrm{m}, \mathrm{a}(\mathrm{f} \Omega \mathrm{m}$. issues discussed in the second half of the letter ( $7 \mathrm{ff}$.) as structuring mechanism, he continues to reflect on the much discussed first part of the letter. He suggests that this part should be seen as focussing on the divisions in the church as is proven by a comparison of the letter with official letters. This comparison indicates that it responded to a letter brought to Paul by a delegation who delivered it only after an oral presentation to Paul. The second half with the four $\square \mathrm{m}, \square)(\Omega \mathrm{m}$, parts responded to the written letter. The first part of 1 Corinthians is a response to the oral presentation.

In this way a formal analysis now confirms what was previously only argued in the light of the contents of the letter. What can be argued from the semantic reading, is now being confirmed by literary analysis. Research on 1 Corinthians is advanced meaningfully by this insight.

\section{Letter Writing, Orality and Personal Presence}

One of the most striking aspects of this book is the insight it provides in letter writing, orality and personal presence. Stirewalt, referring to the general distrust of letter writing in antiquity, noted that a letter was delivered by a personal messenger who extended the presence of the author. The reading aloud of the letter intensified this presence and solidified the social relationship between the parties (Aune 1987:197; Stirewalt 1993:5; Doty, 1973:12; Head 2001). The creation of a sense of personal presence was a key function of letter writing and delivery. ${ }^{16}$

The focus on relaying a sense of the personal is to be understood within the larger context of Pauline writing, which, according to Stirewalt (2003:22) reveals that letters "are part of an interrupted but ongoing conversation with the churches; they are responses to oral and written reports from the people - the oral by his own emissaries or by representatives from the churches. As continued conversation the letters were prepared with an immediacy peculiar to their situation, even with a tentativeness in expectation of

16. The notion that the presence of the author was extended by his letters, was, of course, already important to Deissmann. Deissmann thought that letters intended to continue conversation about real life issues rather than present universal topics for general audiences (Hester s.a.). 
continuing dialogue in person or by letter or emissary." "Reading aloud," so seminal to Pauline texts, "re-animated the written word and secured the sense of the writer's presence" (Stirewalt 2003:16).

This notion of presence explains many literary features of Pauline letters. What may seem to be simple stylistic features, actually promotes the oral presentation of letters within the official space of gathered communities. The rhetorical nature of Pauline letters should also be understood in the light of this oral presentation. Aune (1987:197) noted that written letters and oral discourse were closely related in the ancient world generally. ${ }^{17}$ Written communication has to compensate for the lack of the latter, but has the advantage of integrating complexities that can be recognised through rereading. Letters, nevertheless, delivered by messengers and presented orally, "could function in almost as many ways as speech" (Aune 1987:158, 192 $2^{18}$ ).

It is when this sense of the personal presence of the author is spelled out that interesting notes on spirituality of letters actually seem to be made. Letters, as Aune (1987:186) also indicates, reflect intimacy between sender and audience in more than one way. According to Stirewalt (2003:22), a prime example of such intimacy is found in the letter to the Philippians where the extempore production that causes a lack of predetermined sequence reflects a deeply affectionate engagement with them. Romans, again, reveals a reflective, contemplative Paul at a critical juncture in his ministry and life, using the form of the letteressay to write a "heart-rending" passage concerning the salvation of the Jews and to take "the opportunity to record his own internal, lifelong struggle in this fuller response" and "to review his ministry as consecrated by the gospel in the life of faith." ${ }^{, 19}$ It is a pity that this notion of presence cannot be worked out more extensively in order to understand how letters promotes the shared experience of faith between those who were separated by distance.

Letters, in fact, grew into more complicated and advanced forms because of the spiritual needs of faith communities. Head (2001) noted in a fascinating article how dominant the genre of letters is in the New Testament, focussing on the personal link that letters generate between senders and recipients. Letters expanded and developed in many different forms and functions as its potential to handle matters over a distance became evident. They remained typical "in organization and in formulaic phrasing" the "richness and multiplicity of ancient letter writing practices made letters a powerful communicative force within the early Christian church. These letters pursue many activities - including narrative of remarkable events, proselytizing, prayer, consolation, moral teachings, praise of the faithful and warning against deceivers, philosophic thought, prophesy, and church organization. These letters are regularly framed in forms of fellowship that reaffirm bonds of communality and faith, giving a personal cast of fellowship to the wide range of activities carried out in the New Testament. In the early church letters seemed an important vehicle in maintaining the fellowship of the church over distances."

17. Cf. similar remarks by Stowers as quoted by Stirewalt (2003:23). Aune warns, though, (1987:159) that this relationship can be exaggerated He also discusses how oral communication tends to be linear and determined by paralinguistic features like gesture, tempo, inflection, rhythm and voice quality.

18. He notes the oral nature of literary forms incorporated in the central sections of early Christian letters, thereby illustrating the oral nature of the communicative setting of Christian communities. Note also his remark on this page that Paul and other Christian epistolographers intended their letters to be read aloud.

19. Note similar remarks on 1 Thessalonians, where Paul intertwines the message of the gospel with personal friendship. In 1 Thessalonians 2-3 he expresses deep feelings of friendship, which is fundamentally a sharing of his own self with the readers (Stirewalt 2003:60-1). 
Stirewalt's book brings this to the fore in more than one place. His discussion that is so helpful in understanding specific Pauline letters in the light of official letter writing, suggests new avenues for understanding the communicative dynamics and intimate relationships in New Testament texts.

\section{Conclusion}

This new publication on Paul as letter writer is not only attractive in its published format, beautifully presented with a portrait of Paul by Rembrandt on its cover, clearly and logically written, ${ }^{20}$ but it is a special book in terms of its contents that brings one so close to a proper and sometimes surprisingly new understanding of New Testament texts. For those who wish to understand more of the Pauline literature, it will provide useful and important information - also for further reflection an research. This short, introductory report on the book within its research context cannot do justice to it. It is a book that asks to be read carefully.

20. It sadly lacks indices, though. 


\section{BIBLIOGRAPHY}

Aune, DE 1987. The New Testament in its Literary Environment. Philadelphia: Westminster.

Arzt, P 1994. The Epistolary Introductory Thanksgiving in the Papyri and Paul. NovT 36, 29-46.

Bahr, GJ 1966. Paul and Letter Writing in the First Century. $C B Q 28(1966), 467 \mathrm{ff}$.

Bahr, GJ 1968. The Subscriptions in the Pauline Letters. JBL 87.

Berger, K 1974. Apostelbrief und apostolische Rede: Zum Formular frühchristlicher Briefe. ZNW 65, 191-207.

Betz. HD 1979. Galatians. Philadelphia: Fortress.

Bradford Welles, C 1934. Royal Correspondence in the Hellenistic Period. New Haven: Yale University Press.

Cancik, H 1967. Untersuchungen zu Seneca Epistulae Morales. Hildesheim: Ohlms.

Dahl. N 1976. IDB. s.v. Letters.

Deissmann, A 1901. Bible Studies. Edinburgh: Clark.

Deissmann, A 1927. Light from the Ancient East. London: Hodder \& Stoughton.

Doty, WG 1969. The Classification of Epistolary Literature. CBQ 31, 183-99.

Doty, WG 1973. Letters in primitive Christianity. Philadelphia, Fortress.

Epp, EJ 1991. New Testament Papyrus Manuscripts and Letter Carrying in Greco-Roman times, in Pearson, BA, The Future of Early Christianity. Essays in Honor of Helmut Koester. Philadelphia: Fortress, 35-56.

Exler, FJ 1976 (1923). The Form of the Ancient Greek Letter of the Epistolary Papyri.Chicago: Ares.

Finkenrath, G 1986. Epistole, in Brown, C, (ed.), New Testament Theology. Carlisle: Paternoster, 246-9.

Funk, RW 1967. The Apostolic Parousia. Form and Significance, in Farmer, WR, Moule, CFD and Niebuhr, RR. Christian History and Interpretation. Cambridge: Cambridge University Press, 29-68.

Head, PM 2001. Papyrology: Session 3: Greek Letters. Web Page: http://www.tyndale.cam.uk/Tyndale/stafff/Head/Staff.htm.

Hellholm, D 1986. The Problem of Apocalyptic Genre and the Revelation of John. Semeia 36, 13-64.

Hercher, R 1873. Epistolographi Graeci. Paris: Didot.

Hermann. P 1901. Der Brief in der römischen Literatur. Leipzig: Teubner.

Hester, JD s.a. Rhetoric and the Composition of the Letters of Paul. Web Page: http://www.rhetjournal.net/HesterComp.html.

Kim, CH 1972. The Form and Structure of the Familiar Greek Letter of Introduction. Missoula: Society of Biblical Literature.

Koskenniemi, H 1956.Studien zur Idee und Phraseologie des griechischen Briefen bis 400 n.Chr. Helsinki: Annales Academiae Fennicae.

Longenecker, RN 1974. Ancient Amanuenses and the Pauline Epistles, in Longenecker, RN and Tenney, MC. New Dimensions in New Testament Study. Grand Rapids: Zondervan, 281-97.

Malherbe, AJ 1988. Ancient Epistolary Theorists. Atlanta: Scholars.

Meecham, HG 1923. Light from Ancient Letters. London: Allen \& Unwin. 
Meeks, W 1983. The First Urban Christians. New Haven: Yale University Press.

Mitchell, MM 1992. New Testament Envoys in the Context of Greco-Roman Diplomatic and Epistolary Conventions: The Example of Timothy and Titus. JBL 111, 641-662.

Mullins, T 1962. Petition as a Literary Form. NovT 5, 46-54.

Mullins, T 1964. Disclosure: A Literary Form in the New Testament. NovT 7, 44-50.

Mullins, T 1968. Greeting as a New Testament Form. JBL 87, 418-26.

Mullins, T 1972. Formulas in New Testament Epistles. JBL 91, 380-90.

Ramsay, WM 1904. Letters to the Seven Churches. London: Hodder \& Stoughton.

Reed, J 1996. Are Paul's Thanksgivings “Epistolary”? JSNT 61, 87-99.

Richards, ER 1991. The Secretary in the Letters of Paul. Tübingen: Mohr.

Rigaux, B 1962. Letters of St. Paul: Modern Studies. Chicago: Franciscan Herald Press.

Roller, O 1933. Das Formular der paulinischen Briefe. Stuttgart: Kohlhammer.

Sanders, JT 1962. The Transition from Opening Epistolary Thanksgiving to Body in the Letters of the Pauline Corpus. JBL 71, 348-57.

Schneider, J 1954. Reallexikon für Antike und Christentum, art. "Brief."

Schnider, F and Stenger, W 1987. Studien zum neutestamentlichen Briefformular. Leiden: Brill.

Schubert, P 1939. The Form and Function of the Pauline Thanksgiving. Berlin: Töpelmann.

Stirewalt, ML 1969. Paul's Evaluation of Letter-Writing, in Myers, JM (ed.). Search the Scriptures. Leiden: Brill, 179-196.

Stirewalt, ML 1993. Studies in Ancient Greek Epistolography. Atlanta: Scholars.

Stirewalt, ML 2003. Paul, the Letter Writer. Grand Rapids: Eerdmans.

Stowers, SK 1986. Letter Writing in Greco-Roman Antiquity. Philadelphia: The Westminster Press.

Thraede, K 1970. Grundzüge griechisch-römischer Brieftopik. Münich: Beck.

White, JL 1971. Introductory Formulae in the Body of the Pauline Letter. JBL 90, 91-97.

White, JL 1972. The Form and Structure of the Official Petition. A Study in Greek Epistolography. Missoula: University of Montana Press.

White, JL 1972. The Form and Function of the Body of the Greek Letter: A Study of the Letter-Body in the Non-Literary Papyri and in Paul the Apostle. SBLDS 2. Missoula: Scholars Press.

White, JL 1972. The Form and Structure of the Official Petition. SBLSD 5. Missoula: Scholars Press.

White, JL (ed.) 1982. Studies in Ancient Letter Writing. Semeia 22.

White, JL 1982. The Ancient Epistolography Group in Retrospect. Semeia 22, 1-14.

White, JL1984. New Testament Epistolary Literature in the Framework of Ancient Epistolography. ANRW II.25.2, 1730-56.

White, JL 1986. Light from Ancient Letters. Philadelphia: Fortress.

White, JL 1988. Ancient Greek Letters, in Aune, D (ed.) Graeco-Roman Literature and the New Testament. Atlanta: Scholars Press. 